\title{
The Effect of Human Resources Competencies and Internal Controlling System on the Quality of Accounting Information System and Their Impacts to the Quality of Financial Reporting
}

\author{
Martina Melissa Loudoe ${ }^{1} \&$ Fardinal $^{2}$ \\ ${ }^{1}$ Accounting Department, Mercu Buana University Jakarta, Indonesia \\ Correspondence: Martina Melissa Loudoe, Accounting Department, Mercu Buana University Jakarta, Indonesia. \\ E-mail: marelizcha@gmail.com
}

Received: November 9, 2021

Accepted: December 11, 2021

Online Published: December 23, 2021

doi:10.20849/ajsss.v6i5.965

URL: https://doi.org/10.20849/ajsss.v6i5.965

\begin{abstract}
This study aims to determine the effect of human resources competencies and internal controlling systems on the quality of accounting information systems and to deter-mine the quality of financial reporting. This study is a quantitative study with primary data obtained from 105 respondents from the finance/administration/budget division of the DKI Jakarta Provincial Government SKPD who collected 52 SKPD. Partial Least Square is used as an analytical tool in this study.

The results showed that the competence of human resources and internal controlling systems directly have a significant effect on the quality of accounting information systems and the quality of accounting information systems have a significant effect on the quality of financial reporting.
\end{abstract}

Keywords: competency of human resources, internal control system, quality of accounting information system, quality of financial reporting

\section{Introduction}

DKI Jakarta is a city with many roles, namely as the center of government, the center of economic activity, the center of trade, the center of banking and financial services, and also the main gateway for foreign tourists (https://jakarta.go.id/). Good governance is the most prominent issue in the management of government today. Transparency in financial management is one of the main indicators emphasized by the government to prevent corruption and to realize good governance. Financial reports are a form of financial management, which means information that is expected to be able to provide assistance for users to make economic decisions that are financial in nature (Farid and Siswanto, 2011).

The accounting information system is a system needed by local governments to submit these financial reports. In accordance with Governor Regulation No. 142 of 2013 concerning Regional Financial Management of the Provincial Government of the Special Capital Region of Jakarta, in order to assist the recording of regional financial administration, the DKI Jakarta Provincial Government of Communication, Information and Statistics established the Regional Financial Management Information System (SIPKD). ). An integrated application that is used as a tool for regional governments, especially the DKI Jakarta Provincial Government, which is used to increase the effectiveness of the implementation of various regulations in the field of regional financial management based on the principles of efficiency, economy, effectiveness, transparency, accountability and auditability. (reported by https://sipkddki.jakarta.go.id)

Based on the Audit Opinion of the Regional Government Financial Reports (LKPD) of the DKI Jakarta Provincial Government by the Supreme Audit Agency (BPK) from 2013 to 2016 or for 4 consecutive years it received a Fair With Exception (WDP) opinion, but in 2017 it received an opinion Unqualified (WDP). Phenomena that occurred during the audit year were problems with weaknesses in the internal controlling system, problems with non-compliance with statutory provisions, and problems with thrifty, inefficiency and ineffectiveness (reported by https://www.bpk.go. id/ihps). 
Research conducted by Lari Dashtbayaz, M., Salehi, M., \& Safdel, T. (2019) in which the results illustrate that weaknesses in internal controlling have a significant negative relationship with financial reporting quality. In other words, the weakness of internal controlling reduces the quality of financial reporting.

The phenomenon related to the accounting information system was also stated by BPK in 2015. For this reason, BPK suggested several things to be improved. For example, a motor vehicle tax receivable recording system using an application system that can guarantee the validity of data on the number of taxpayers, along with the amount of their obligations to comply with the provisions and needs of accrual-based recording (reported by https://news.detik.com). The recording system that is carried out requires a subject to run it, namely human resources. Someone who has competence will work with his knowledge and skills so that he can work easily, quickly, intuitively and with his experience to minimize errors (Nike \& Ade, 2018). The results of Setiyawati's research (2013) stated that the internal accountant's competences have a positive effect on the quality of financial reporting. The results of Fitrios' research (2016) showed that user training affects the accounting information system implementation.

Based on the phenomena and previous research, the problems identified in this study are: (1) How much human resource competenceiese has an effect on the quality of accounting information systems, (2) How much does the internal controlling system affects the quality of information systems? accounting, (3) How much the quality of accounting information system affects the quality of financial reporting.

\section{Research Method}

\subsection{Type of Research}

The research method employed in this research methods. Quantitative research methods are research methods based on the philosophy of positivism, used to examine certain populations or samples. (Lela, 2018:8).

\subsection{Definition of Variable Operationalization and Variable Measurement}

\subsubsection{Human Resources Competenciese (Variable X1)}

Competenciese of human resources is an integrated ability of the power of thought and physical power possessed by individuals. Human resources are the main key for the organization in carrying out its goals. No matter how sophisticated the tools used in the organization are, if they are not accompanied by the capabilities of their human resources, it is certain that organizational processes cannot run smoothly (Ajabar, 2020: 4). Dimensions of resource competence human beings based on the type of competence, namely: intellectual competence, emotional competenciese and social competence.

\subsubsection{Internal Controlling System (variable X2)}

Fauzi (2017: 64) states that internal control is an organizational plan and business method used to safeguard assets, provide accurate and reliable information, encourage and improve the efficiency of the organization's operations and encourage conformity with established policies. The dimensions of the internal controlling system are based on the internal controlling components, namely: control environment and control activities.

\subsubsection{Quality of Accounting Information System (Variable Y)}

According to Barry E. Caushing, AIS is a collection of human and capital resources in an organization that is responsible for providing financial information as well as information obtained from the collection and processing of transaction data (Fauzi, 2017: 25). The dimensions of the quality of the accounting information system are based on the components of internal control, namely: transaction processing system (TPS) and general ledger/financial reporting system (GL/FRS).

\subsubsection{Quality of Financial Reporting (Variable Z)}

The quality of financial reporting is a broad concept, not only referring to financial information, but also disclosure and non-financial information that is useful for decision making. (Winwin et al, 2017: 29). Financial statements are basically the result of the accounting process that can be used as a tool to communicate financial data or company activities to interested parties. (Hery 2017:6). The dimensions of financial reporting quality according to Indonesian Government Accounting Standards (SAP) (2010) are as follows: (1) Relevant, (2) Reliable, (3) Comparable, (4) Understandable.

\subsection{Population and Research Sample}

The population in the study in the Regional Working Units (SKPD) of the DKI Jakarta Provincial Government, amounting to 52 SKPD. As for the research sample, using purposive sampling technique with a total sample of 156 people who responded. The criteria used are: 
a. Official/functional employee of the finance/administrative/budget division of the DKI Jakarta Provincial Government SKPD.

b. Has been actively involved for at least one year in financial management in the working unit.

In this study, the data collection technique used is a survey technique which aims to obtain respondent's opinion data through a questionnaire instrument. Secondary data obtained by researchers from various existing sources such as books, documents, reports, journals that have been published.

\subsection{Analysis Method}

This study uses an associative descriptive method with the type of research study a survey approach. Data analysis method using Smart PLS (Partial Least Square) software version smartpls 3.0. The data analysis method in this study is divided into three, namely:

\subsubsection{Descriptive Statistical Analysis}

Descriptive analysis is used to describe research variables, without drawing generalizations. The data that has been collected is then tabulated in a table and descriptively discussed. Descriptive measure is the provision of numbers, both in the number of respondents along with the average value of respondents' answers and in the form of percentages. (Lela, 2018:118).

\subsubsection{SEM PLS Second Order Confirmatory Analysis}

Second Order Confirmatory PLS SEM analysis is used to test how well the measured variables can represent the constructs or factors that were formed previously. In CFA, there are two kinds of variables, namely latent variables and indicator variables. In SEM there are 3 activities simultaneously, namely checking the validity and reliability of the instrument (confirmatory factor analysis), testing the relationship model between variables (path analysis), and getting a suitable model for prediction (structural model analysis and regression analysis).

\subsubsection{Hypothesis Testing}

The size of the significance of the support of the hypothesis can be used to compare the values of the T-table and T-statistics. The criteria for testing the hypothesis in this study are the significance level $(\alpha) 5 \%$ and are determined by the following criteria:

- If $t$ count $>t$ table (1.96) then the hypothesis is accepted

- If $\mathrm{t}$ count $<\mathrm{t}$ table (1.96) then the hypothesis is rejected

Hypothesis testing can also be determined by $\mathrm{P}-\mathrm{Value}$ with the following criteria:

- If P-Value <0.05 then the hypothesis is accepted

- If P-Value $>0.05$ then the hypothesis is rejected

\section{Data Analysis and Discussion}

\subsection{Descriptive Statistical Analysis}

The results of this descriptive test in the form of the average value (mean) of the respond-ents' answers. The average value of the respondents' answers are then grouped in a certain interval according to research variables. The average value of each variable in this study and its categorization can be seen in the following table:

Table 1

\begin{tabular}{lccc}
\hline & Indicators & Mean & Categories \\
\hline Information mastery (X1.1.1) & 4,771 & Very high \\
Information mastery (X1.1.2) & 3,952 & High \\
Practical skills (X1.2.1) & 4,210 & Very high \\
Practical skills (X1.2.1) & 4,571 & Very high \\
Self-control (X1.3.1) & 4,705 & Very high \\
Self-control (X1.3.2) & 4,400 & Very high \\
Confident (X1.4.1) & 4,629 & Very high \\
Confident (X1.4.2) & 4,267 & Very high
\end{tabular}


Organizational awareness (X1.5.1)

4,305

Organizational awareness (X1.5.2)

Building working relationships (X1.6.1)

Building working relationships (X1.5.2)

Organizational integrity and ethical values (X2.1.1)

Organizational integrity and ethical values (X2.1.1)

Firmness to encourage work accountability (X2.2.1)

Firmness to encourage work accountability (X2.2.2)

The Inspectorate controls the overall recording of financial transactions

(X2.3.1)

The Inspectorate controls the overall recording of financial transactions

(X2.3.2)

The Inspectorate always provides assistance and reviews in the preparation of

LK (X2.4.1)

The Inspectorate always provides assistance and reviews in the preparation of

LK (X2.4.2)

The program can perform its functions correctly and completely (completeness)

(Y.1.1)

The program can perform its functions correctly and completely (completeness)

(Y.1.2)

Program protected and easy to maintain (maintanance) (Y.1.3)

Program protected and easy to maintain (maintanance) (Y.1.4)

Recording (Y.2.1)

Recording (Y.2.2)

Classification (Y.3.1)

Reporting (Y.4.1)

On time 1 (Z.1.1)

On time 1 (Z.1.2)

Complete 1 (Z.2.1)

Complete 1 (Z.2.2)

Honest presentation (Z.3.1)

Honest presentation (Z.3.2)

Verifiability (Z.4.1)

Verifiability (Z.4.2)

Can be compared with the previous period (Z.5.1)

Can be used as a basis for prediction (Z.6.1)

Information presented in accordance with Government Accounting Standards (Z.7.1)

Information presented in accordance with Government Accounting Standards (Z.7.2)

Interpretation of information is easy to understand (Z.8.1)
4,743

4,571

4,686

4,248

4,390

4,419

4,533

4,219

4,343

4,419

4,286

4,495

4,514

4,114

4,219

4,638

4,733

4,590

4,457

4,486

4,495

4,619

4,486

4,514

4,314

4,552

4,543

4,533

4,429

4,590

4,581

4,467
Very high

Very high

Very high

Very high

Very high

Very high

Very high

Very high

Very high

Very high

Very high

Very high

Very high

Very high

Very high

High

Very high

Very high

Very high

Very high

Very high

Very high

Very high

Very high

Very high

Very high

Very high

Very high

Very high

Very high

Very high

Very high

Very high 


\subsection{Second Order Confirmatory PLS SEM Analysis}

\subsubsection{Validity and Reliability Testing (Outer Model)}

Based on the results of the convergent validity test, the question indicators in this study from X1.1.1 to Z.8.1 each showed a significant correlation, which is above 0.70 (loading factor value), so it can be stated that each variable indicator in this study is valid.

Tests with composite reliability for almost all variables the reliability value reaches 0.70 . This shows that all the variables in the estimated model meet the composite reliability criteria, so that all indicators in this study are feasible and reliable to be applied.

In addition, the reliability test using Cronbach's Alpha on all questionnaire variables is in the range of values of 0.60 or more. This means that the indicators that have been used are reliable and reliable for a study.

\subsubsection{Evaluation of Goodness of Fit Structural Model (Inner Model)}

Based on the coefficient of determination, ni R2 is obtained for the accounting information system quality variable of 0.604 , which means that this value indicates that the accounting information system quality variable (Y) can be explained by the human resource competency variable (X1) and the internal control system (X2). by $60 \%$, while the remaining $40 \%$ is influenced by other variables not included in this study.

The R2 value for the financial reporting quality variable is 0.808 , which means that the financial reporting quality variable $(\mathrm{Z})$ can be explained by the variable of human resource competenciese (X1) and internal controlling system (X2) as much $80 \%$, while the remaining $20 \%$ is influenced by other variables not included in the research model.

The results of the R-square test explain that the relationship between latent variables used in this study is moderate (medium). The value of R2 in each variable is used as the basis for calculating predictive-relevance (Q2).

The evaluation of the inner model is quite good in explaining the quality of accounting information systems and the quality of financial reporting. Meanwhile, the predictive-relevance value for the structural model in this study is 0.673 or $67 \%$, meaning that the model is able to explain the phenomenon of financial reporting quality associated with several variables, namely human resource competencies, internal control systems and the quality of accounting information systems. Therefore, the model can be said to be good, or the value has a good predictive value. In the end the model can be used for hypothesis testing.

\subsubsection{Hypothesis Test}

A variable can be said to be significant if it has a P-value that is smaller than 0.05 (p-value <0.05) and has a t-statistics value that is greater than the t-table 1.96. Based on the test of the dimensions of the research variables, it can be seen that all indicators have a p-value that is smaller than 0.05 and has a t-statistics value that is greater than a t-table of 1.96 .

Table 2. Hypothesis result value

\begin{tabular}{lcccc}
\hline \multicolumn{1}{c}{ Variable } & $\begin{array}{c}\text { Koefisien } \\
\text { Parameter }\end{array}$ & T Statistics & $\begin{array}{c}\text { P } \\
\text { Values }\end{array}$ & Keterangan \\
\hline $\begin{array}{l}\text { Human Resources Competenciese -> } \\
\text { Quality of Accounting Information System }\end{array}$ & 0,553 & 6,560 & 0,000 & Significant** \\
$\begin{array}{l}\text { Internal Controlling System -> Quality of } \\
\text { Accounting Information System } \\
\text { Quality of Accounting Information System }\end{array}$ & 0,329 & 3,197 & 0,001 & Significant** \\
$\rightarrow$ Quality of Financial Reporting & 0,835 & 30,125 & 0,000 & Significant** \\
\hline
\end{tabular}

The results of testing the first hypothesis indicate that there is a positive and significant influence between human resource competencies on the quality of accounting information systems at a significant level of $5 \%$, with a path coefficient of 0.553 . The results of testing the second hypothesis indicate that there is a positive and significant effect between the internal controlling system on the quality of the accounting information system at 
a significant level of $5 \%$, with a path coefficient of 0.329 . The results of testing the second hypothesis indicate that there is a positive and significant effect between accounting information systems on the quality of financial reporting at a significant level of $5 \%$, with a path coefficient of 0.329 .

\subsection{Discussion}

3.3.1 The Influence of Human Resources Competenciese (X1) on the Quality of Accounting Information Systems (Z)

Based on the results of statistical tests and significance that the competenciese of human resources has a positive and significant effect on the quality of accounting information systems. This means that the better the competenciese of human resources in an SKPD, the better the quality of the accounting information system produced will be. The competencies of human resources in the DKI Jakarta Provincial Government SKPD has competencies that are in accordance with their respective functions. Intellectual competenciese possessed by employees improves the quality of the work produced. Based on the survey results, the largest contribution to human resource competencies is social competence. Social competence is the character of attitudes and behavior or the willingness to build cooperative nodes with others when facing problems at work.

The results of this study are in line with Syarifudin (2014) which shows that HR competence has a significant effect on SPIP, so that a high level of competence will further increase the effectiveness of SPIP.

\subsubsection{Effect of Internal Controlling System (X2) on Quality of Accounting Information System (Y)}

Based on the statistical test results and the significance that the internal controlling system has a positive and significant effect on the quality of the accounting information system. This means that the stronger the internal controlling system in an SKPD is, the better the quality of the accounting information system produced will be. A good organizational structure, division of tasks, authorities and responsibilities according to SOPs will create a healthy control environment. The largest contribution to the survey related to the internal controlling system is control activities. The control activity component includes policies and procedures to help ensure that the necessary actions are taken to address risks in order to achieve the entity's objectives (COSO, 2013). Control activities such as controlling the overall recording of financial transactions, assistance and reviews in recording financial transactions, assistance and reviews in the preparation of financial reports carried out by the inspectorate have an impact on the quality of the accounting information system produced by each SKPD.

The results of this study are in line with research by Ramdany (2015) that there is a positive relationship between the quality of accounting information systems and the effectiveness of internal controls on the quality of financial re-ports. In other words, the quality of financial reporting can be improved through improving the quality of accounting information systems and the effectiveness of internal controls.

\subsubsection{Effect of Quality of Accounting Information System (Y) on Quality of Financial Reporting (Z)}

Based on the results of statistical tests and significance that the quality of the accounting information system has a positive and significant effect on the quality of financial reporting. This means that the better the quality of the accounting information system in an SKPD, the better the quality of financial reporting will be. SIPKD is an application developed by the DKI Jakarta Provincial Government of Communication, Information and Public Relations in order to assist the recording of regional financial administration which can minimize costs, time and information resources. (https://sipkddki.jakarta.go.id/). The biggest contribution to the quality of the accounting information system is the general ledger/financial reporting system. The application of the general ledger system and financial reporting has a great role and benefit for the ongoing activities of the company. The general ledger system that is implemented in each SKPD, such as a complete record of expenditures, with the required data and documents, which have been ensured to be available and accurate, will facilitate the accounting process. In addition, the classification of transactions carried out according to the type of transaction is very helpful in the application of the general ledger system, which plays an important role in AIS.

The results of this study are consistent with the research of Sugara (2015) which states that the implementation of accounting information system has significant effects on the quality of financial reporting.

\section{Conclusion}

Based on the data obtained and the results of the analysis that has been carried out, conclusions can be drawn regarding the influence of Human Resource Competence and Internal Controlling Systems on the Quality of Accounting Information Systems and their Impact on the Quality of Financial Reporting as follows:

a. Competence of human resources has a significant effect on the quality of accounting information systems.

b. The Internal Controlling System has a significant effect on the quality of the accounting information system. 
c. The quality of the accounting information system has a significant effect on the quality of financial reporting. The function of the accounting information system itself is to produce financial reports that will be used by various interested parties.

\section{References}

Committee of Sponsoring Organization (COSO) of The Treadway Commission. (2013). Internal Control Integrated Framework: Executive Summary. COSO.

Dinas Komunikasi, \& Informatika dan Kehumasan Pemprov DKI Jakarta. (2015). Sistem Informasi Pengelolaan Keuangan Daerah. Diakses pada tanggal 3 Mei 2021 dari SIPKD DKI Retrieved from https://sipkddki.jakarta.go.id/index.htmlArens. 2008. Auditing dan Jasa Assurance Pendekatan Terintegrasi. Jilid i. Edisi 12. Jakarta: Erlangga.

Dinas Komunikasi, \& Informatika dan Kehumasan Pemprov DKI Jakarta. (2021). Tentang Jakarta. Diakses pada tanggal 3 Mei 2021 dari Jakarta.go.id. Retrieved from https://jakarta.go.id/tentang-jakarta

Fauzi, R. A. (2017). Sistem Informasi Akuntansi (Berbasis Akuntansi). Sleman: Deepublish.

Hery. (2017). Teori Akuntansi - Pendekatan Konsep dan Analisisi. Jakrarta: PT. Grasindo.

Lela Nurlaela Wati (2017). Metodologi Penelitian: Bisnis Terapan. Bandung: Mujahid Press.

Moeheriono. (2012). Pengukuran Kinerja berbasis Kompetensi Edisi Revisi. Bogor: Ghalia.

Ramdany. (2015). Influence the Quality of Accounting information Systems and The Effectiveness of Internal Control on Financial Reporting Quality. Research Journal of Finance and Accounting, 6(6). Retrieved from www.iiste.org

Willy Abdillah dan Jogiyanto. (2015). Partial Least Square (PLS): Alternative Structural Equation Modelling (SEM) dalam Penelitian Bisnis. Yogyakarta: Penerbit Andi.

Yusar Sugara. (2015). The Effect of Implementation Accounting Information System and Competence of Human Resources on the Quality of Financial Reporting. Research Journal of Finance and Accounting, 6(10).

\section{Copyrights}

Copyright for this article is retained by the author(s), with first publication rights granted to the journal.

This is an open-access article distributed under the terms and conditions of the Creative Commons Attribution license (http://creativecommons.org/licenses/by/4.0/). 